\title{
UNDERSTANDING ANTECEDENTS TO THE SATISFACTION OF USING LEARNING MANAGEMENT SYSTEM: AN EMPIRICAL STUDY OF ACCOUNTING STUDENTS
}

\author{
Selfira Salsabilla ${ }^{*}$ \\ Universitas Islam Indonesia \\ Kaliurang St., Yogyakarta, \\ Indonesia 55584 \\ selfirasalsabilla@uii.ac.id
}

\author{
Chivalrind Ghanevi Ayuntari² \\ Universitas Islam Indonesia \\ Kaliurang St., Yogyakarta, \\ Indonesia 55584 \\ chivalrind.ghanevi@uii.ac.id
}

\begin{abstract}
This research was aimed to identify the factors affecting the Accounting students' satisfaction of using Google Classroom as one of the Learning Management System (LMS). This research analyzed the effect of perceived enjoyment, perceived ease of use, and perceived usefulness on the students' satisfaction. The sample in this research was 108 Accounting students. The data were analyzed using PLS-SEM with SmartPLS 2.0. The research results showed that the level of satisfaction of the Google Classroom was affected positively and significantly by the perceived enjoyment, perceived ease of use, and perceived usefulness. Moreover, this research also discussed the impacts of the results both theoretically and practically.
\end{abstract}

Keywords: $\quad$ Perceived ease of use; Perceived enjoyment; Perceived usefulness; Satisfaction

\begin{abstract}
ABSTRAK
Penelitian ini bertujuan untuk mengidentifikasi faktor-faktor yang mempengaruhi kepuasan mahasiswa akuntansi dalam menggunakan google classroom yang merupakan salah satu learning management system (LMS). Penelitian ini menganalisis pengaruh perceived enjoyment, perceived ease of use, perceived usefulness terhadap kepuasan. Penelitian ini menggunakan sampel 108 responden mahasiswa akuntansi. Data dianalisis menggunakan PLS-SEM dengan software SmartPLS 2.0. Hasil penelitian menunjukkan bahwa tingkat kepuasan terhadap google classroom dipengaruhi secara positif signifikan oleh perceived enjoyment, perceived ease of use, dan perceived usefulness. Penelitian ini juga mendiskusikan dampak hasil penelitian dalam ranah teoritis dan praktis.
\end{abstract}

Kata Kunci: $\quad$ Persepsi kemudahan; Persepsi kesenangan; Persepsi kegunaan; Kepuasan

JEL Classification: A220; M490

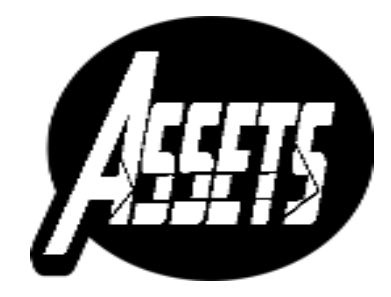

ASSETS

Jurnal Akuntansi dan Pendidikan

Vol. 9 No. 2

Page 109-120

Madiun, October 2020 p-ISSN: 2302-6251 e-ISSN: 2477-4995

Article History Submitted: August 13, 2019 Accepted: August 31, 2020 


\section{INTRODUCTION}

One of the crucial elements in conducting successful e-learning activities in a teaching and learning process is the Learning Management System (LMS) - a software that supports e-learning activities (Dash, 2019; Yalcin \& Kutlu, 2019). LMS is believed to give an essential contribution to today's education (Cigdem \& Topcu, 2015). It has been widely used in education, along with the development of the internet and other supporting devices. LMS is an information technology used to organize learning activities (Sezer \& Yilmaz, 2019). Specifically, it is an information technology that enables teachers, lecturers, instructors, and students/college students to share teaching/learning materials, create a class announcement, submit and return assignments, and communicate through an online system (Lonn \& Teasley, 2009). Viewing that through LMS, the learning process can be supervised and evaluated; it means that it can continuously be developed using this software (Sezer \& Yilmaz, 2019). Some of the many LMS are Edmodo, Blackboard, Moodle, eFront, Brightspace, Sakai, Dokeos, and Google Classroom.

The total budget of e-learning (LMS) in Indonesia has been elevating in the last five years (Hidayat, 2018). It would be in vain if students did not get the provided LMS (Jakkaew, 2017). One of the factors of student's acceptance of the information technology during the teaching and learning process is their satisfaction with it (Vaezi, Mills, Chin, \& Zafar, 2016). Regarding this issue, colleges or universities in Indonesia must understand the factors determining the level of student satisfaction of using LMS. Some previous research in the context of information technology has identified the factors affecting satisfaction. They found that perceived usefulness (PU) and perceived ease of use (PEoU) affected the satisfaction (Cho, 2016; Hossain, Nurunnabi, Hussain, \& Saha, 2019; Kholid, Urumsah, \& Hamdani, 2018). Moreover, some other previous research also found the effect of perceived enjoyment (PE) on the satisfaction (Azian, Rahman, Hussein, Rusdi, \& Esa, 2017; Marinkovic \& Kalinic, 2017; Park, 2020). Meanwhile, there was also research confirming that computer self-efficacy (CSE) affected the level of PEoU (Yalcin \& Kutlu, 2019).

Google Classroom is one of the LMS that is lately developing and is widely adopted by colleges/universities (Jakkaew, 2017). It is a web-based LMS that facilitates every user to create and organize online classes as long as they have a Google account (Kumar \& Bervell, 2019). The users will then be able to minimize the use of paper, share learning materials, and improve communication quality between teachers and students (Jakkaew, 2017). Moreover, Google Classroom has more excellence than other LMS, namely easy to use, reliable, and facebook-like interface (Jordan \& Duckett, 2018). Regarding those facts, this research is focused on the factors affecting students' satisfaction of using Google Classroom. Specifically, this research is aimed to investigate the effect of CSE, PEJ, PU, and PEoU on the satisfaction of Accounting students in using Google Classroom as the LMS.

There are some rationales why this research is importantly conducted. First, lecturers must understand how their students view LMS because their perception will affect their involvement in the teaching and learning process (Basioudis, Lange, Suwardy, \& Wells, 2012). Second, some previous research related to LMS such as Dash (2019); Jakkaew, (2017); Kumar \& Bervell (2019); Yalcin \& Kutlu (2019) do not discuss the determinant of satisfaction. Seeing those facts, this research attempts to close the gap of the previous research by focusing on the factors affecting satisfaction. Third, this research involves Accounting students as the subject/respondent. It is based on the previous research that analyzed the use of Google Classroom by respondents from individual students. For example, Dash (2019) focused on students studying 
Biochemistry and Jakkaew (2017) focused on students studying information technology.

The notion of PU means users' perception of the benefits of using information technology, while PEoU means users' perception of the easiness and effortlessness of using information technology (Davis, 1989). PU and PEoU are significant variables that affect attitude (Davis, Bagozzi, \& Warshaw, 1989). Therefore, viewing that satisfaction is an attitude that is a positive and happy feeling; it is logical to hypothesize that PU and PEoU positively affect satisfaction (Cho, 2016). It is in line with some previous research that revealed the positive effect of PU and PEoU on satisfaction (Hayashi, Chen, Ryan, \& Wu, 2004; Joo, Park, \& Shin, 2017; Azian et al., 2017; Cho, 2016; Cheng \& Yuen, 2018; Hossain et al., 2019; Kholid et al., 2018). Moreover, PEoU affects the intention to use information technology through PU (Davis et al., 1989). It indicates that PEoU will affect PU (Cho, 2016). When users feel that information technology is challenging to use, they will view it as vain (Davis, 1989). Some other previous research also found the effect of PEoU on PU (Cho, 2016; Hu \& Zhang, 2016; Natarajan, Balasubramanian, \& Kasilingam, 2017; Yalcin \& Kutlu, 2019).

PEJ means how interesting the activities using information technology are seen by individuals, regardless of the performance consequences resulted from its use (Davis, Bagozzi, \& Warshaw, 1992). Viewing from this perspective, the expectation of a fun experience of users of information technology can be their belief that later can be the key to satisfaction because PU is the user's belief that affects satisfaction (Thong, Hong, \& Tam, 2006). Besides, PEJ can also affect PEoU. It is based on a logical reason that users who enjoy using information technology will not see it hard to use information technology (Thong et al., 2006). Previous research found the effect of PEJ on PEoU (Huang, Teo, \& Scherer, 2020). Self-efficacy means assessing a person's ability to organize and conduct actions needed to achieve the targeted performance (Bandura, 1986). In the field of information technology, CSE is referred to as self-assessment about their ability to use a computer to accomplish their work (Compeau \& Higgins, 1995). CSE is importantly concerned by students using technology in their daily educational practices (Teo, Ursavaş, \& Bahçekapili, 2012). The previous research found the positive effect of CSE on PEoU (Huang et al., 2020; Roca, Chiu, \& Martínez, 2006; Yalcin \& Kutlu, 2019). Based on the literature review conducted, Figure 1 shows the research model on the satisfaction of using LMS.

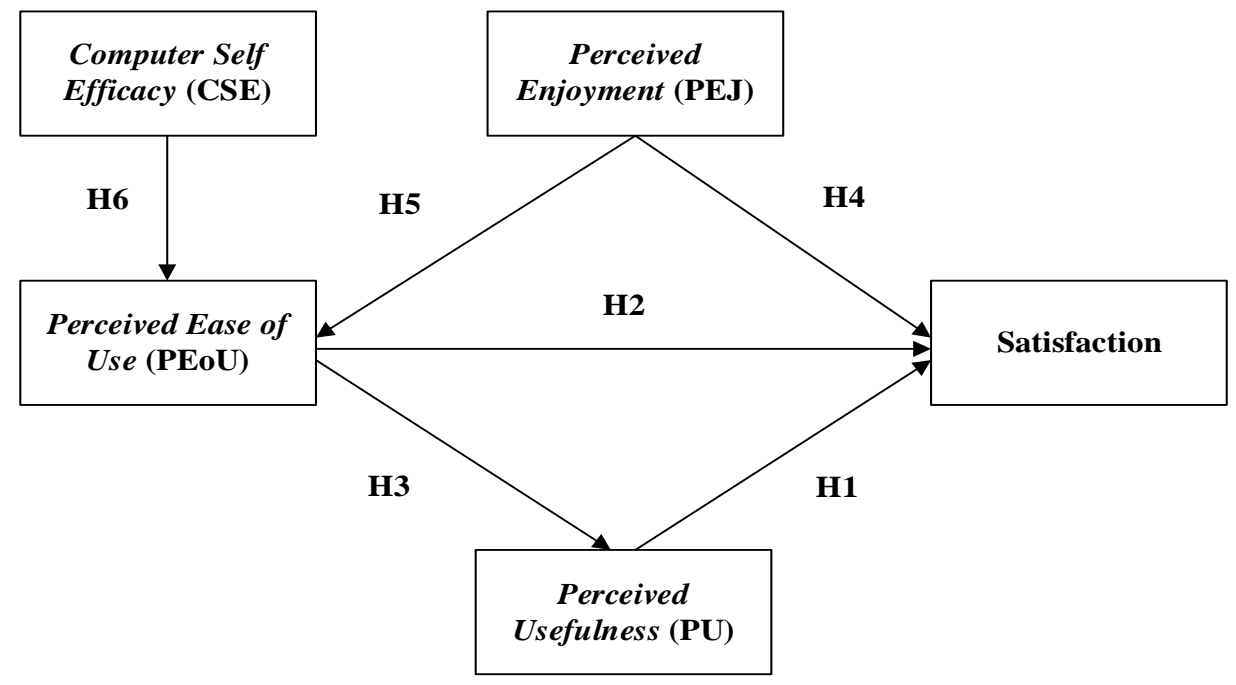

Figure 1. Research Model 


\section{METHOD}

It is quantitative research with a survey method to gain primary data. The population in this study were accounting students in Yogyakarta. The sample was Diploma 3 Accounting students of Universitas Islam, Indonesia, Yogyakarta. One hundred eight respondents were participating in this research. The purposive sampling and convenience sampling techniques were used in this research. Convenience sampling is comfortable and ready to participate in sampling techniques, while purposive sampling is a sampling technique based on the aim/specific criteria (Teddie \& Yu, 2007). The sample in this research was taken according to Accounting students' criteria as the participants who have experienced using Google Classroom.

Data in this research were collected through online questionnaires. Regarding the variable measurement, the satisfaction variable was measured by 3 statement items modified from Roca et al. (2006), the CSE variable was measured by 3 statement items modified from Compeau \& Higgins (1995), and the PEJ variable was measured by 4 statement items modified from Thong et al. (2006). Meanwhile, the other two variables, PU and PEoU, were measured by 3 statement items modified from Davis (1989). The Likert Scale 1 - 6 was used to measure the variables in this research. The scale showed the level of respondent's agreement on each statement of every variable. It starts from scale one, which means 'strongly disagree' to scale six, which means 'strongly agree'.

The data were analyzed using Partial Least Squares - Structural Equation Modeling (PLS-SEM) supported by SmartPLS 2.0 software. PLS-SEM covered the measurement model analysis and structural model analysis (Hair, Hult, Ringle, \& Sarstedt, 2017). The measurement model tested covered the internal consistency that used the value of composite reliability (CR) and Cronbach alpha (Hair et al., 2017). Moreover, the validity test was also conducted; it covered the convergent and discriminant validity (Hair et al., 2017). The convergent validity covered a test with the value of outer loading and average variance extracted (AVE). Meanwhile, the discriminant validity test was conducted using the cross-loading and Fornell-larcker criterion approach. The structural model was used to analyze the correlation between the variables in the research model. It covered the test of coefficient determination (R2), predictive relevance (Q2) dan significance of path coefficient $(\beta)$ (Hair et al., 2017).

\section{RESULT AND DISCUSSION}

The convergent validity test result shows that the value of AVE of each variable is at 0.770 to 0.873 . It means that the convergent validity is achieved because the AVE value of each variable is above 0.5 (Hair et al., 2017). The loading factor's result shows that the value of loading of the variable measurement item is at 0.802 to 0.954 , in which it is more than 0.7. It can be concluded that the construct indicator in the model is valid (Hair et al., 2017). Table 1 shows the results of internal consistency and convergent validity tests.

The value of composite reliability and Cronbach Alpha show the result of the internal consistency test. The value of the composite reliability of each variable is at 0.890 to 0.954 . Meanwhile, the value of Cronbach Alpha is 0.815 to 0.927 . It means that each variable achieves the internal consistency test because the value of both composite reliability and Cronbach Alpha is above 0.7 (Hair et al., 2017). Table 2 shows the results of the discriminant validity test using the Fornell-larcker criterion approach. Viewed in Table 2, the value of AVE square root of each variable is more than the correlation of each construct. It indicates that the discriminant validity test is achieved. Moreover, the discriminant validity test in this research is also viewed from the cross-loading approach. 
Table 1. Measurement Model Assessment: Internal Consistency dan Convergent Validity

\begin{tabular}{lcccc}
\hline Variable and Item & Loading & AVE & Composite Reliability & Cronbach alpha \\
\hline Satisfaction & & 0.770 & 0.909 & 0.850 \\
SA1 & 0.904 & & & \\
SA2 & 0.882 & & & \\
SA3 & 0.846 & & 0.931 & \\
& & & & \\
PEJ & & 0.773 & & \\
PEJ1 & 0.910 & & & \\
PEJ2 & 0.900 & & & \\
PEJ3 & 0.900 & & & \\
PEJ4 & 0.802 & & & \\
& & & & \\
PU & & 0.731 & & \\
PU1 & 0.862 & & & \\
PU2 & 0.887 & & & \\
PU3 & 0.814 & & & \\
PEoU & & & & \\
PEoU1 & & 0.772 & & \\
PEoU2 & 0.835 & & & \\
PEoU3 & 0.898 & & & \\
CSE & 0.901 & & & \\
CSE1 & & & & \\
CSE2 & 0.920 & & & \\
CSE3 & 0.954 & & & \\
\hline
\end{tabular}

Table 2. Measurement Model Assessment: Fornell-Larcker Criterion

\begin{tabular}{lccccc}
\hline \multicolumn{1}{c}{ Variable } & CSE & PEoU & PEJ & $P U$ & Satisfaction \\
\hline CSE & $\mathbf{0 . 9 3 4 4}$ & & & & \\
PEoU & 0.5181 & $\mathbf{0 . 8 5 5 0}$ & & & \\
PEJ & 0.3115 & 0.4269 & $\mathbf{0 . 8 7 9 0}$ & & \\
PU & 0.3044 & 0.3115 & 0.6166 & $\mathbf{0 . 8 5 5 0}$ & \\
Satisfaction & 0.3679 & 0.4249 & 0.6269 & 0.7129 & $\mathbf{0 . 8 7 8 6}$ \\
Note: Diagonal terms (in italic \& bold) are the square roots of the AVE & & \\
\hline
\end{tabular}

Table 3 shows the results of the discriminant validity test using the cross-loading approach. The results of the test show that the loading of each variable indicator is more than the cross-loading. It means that it meets the discriminant validity (Hair et al., 2017). As viewed in Table 3, the CS1 loading on the CSE variable has a value of 0.9200. The value is higher than the CS1 on PEoU (0.4460), PEJ (0.2723), PU (0.3152) and satisfaction (0.3202). 
SALSABILLA, S. \& AYUNTARI, C. G. UNDERSTANDING ANTECEDENTS TO ....

Table 3. Measurement Model Assessment: Cross-Loading

\begin{tabular}{lrrrrr}
\hline & CSE & PEoU & PEJ & PU & Satisfaction \\
\hline CS1 & $\mathbf{0 . 9 2 0 0}$ & 0.4460 & 0.2723 & 0.3152 & 0.3202 \\
CS2 & $\mathbf{0 . 9 5 3 6}$ & 0.4875 & 0.2610 & 0.2478 & 0.3106 \\
CS3 & $\mathbf{0 . 9 2 9 2}$ & 0.5143 & 0.3358 & 0.2927 & 0.3957 \\
PE1 & 0.3950 & $\mathbf{0 . 8 3 5 1}$ & 0.4791 & 0.3008 & 0.3597 \\
PE2 & 0.5055 & $\mathbf{0 . 8 9 8 3}$ & 0.3405 & 0.2738 & 0.3808 \\
PE3 & 0.4639 & $\mathbf{0 . 9 0 1 2}$ & 0.3008 & 0.2449 & 0.3787 \\
PEJ1 & 0.2662 & 0.3565 & $\mathbf{0 . 9 1 0 3}$ & 0.5152 & 0.5322 \\
PEJ2 & 0.2889 & 0.4606 & $\mathbf{0 . 8 9 9 6}$ & 0.4580 & 0.4529 \\
PEJ3 & 0.2642 & 0.3914 & $\mathbf{0 . 8 9 9 7}$ & 0.5624 & 0.5257 \\
PEJ4 & 0.2721 & 0.2970 & $\mathbf{0 . 8 0 2 2}$ & 0.6136 & 0.6697 \\
PU1 & 0.3377 & 0.3112 & 0.4571 & $\mathbf{0 . 8 6 2 3}$ & 0.5813 \\
PU2 & 0.2913 & 0.2872 & 0.5933 & $\mathbf{0 . 8 8 7 0}$ & 0.6515 \\
PU3 & 0.1440 & 0.1961 & 0.5275 & $\mathbf{0 . 8 1 4 0}$ & 0.5937 \\
SA1 & 0.4060 & 0.4580 & 0.5658 & 0.6393 & $\mathbf{0 . 9 0 3 6}$ \\
SA2 & 0.3041 & 0.3705 & 0.5693 & 0.6250 & $\mathbf{0 . 8 8 1 9}$ \\
SA3 & 0.2511 & 0.2814 & 0.5137 & 0.6128 & $\mathbf{0 . 8 4 6 1}$ \\
\hline
\end{tabular}

Regarding the coefficient determination, the value of R2 is divided into 3 model categories, namely robust model (75\%), moderate model (50\%), and weak model (25\%) (25\%) (Hair et al., 2017). Figure 2 is shown that R2 on the satisfaction variable is $58.63 \%$. It shows that the model is in the moderate category because it is above $50 \%$ but under $75 \%$. The value shows that this model can explain the satisfaction level of the use of LMS as much as $58.63 \%$. The rest is explained by the variables that are not included in the model of this research. Meanwhile, PEoU shows that the value of R2 $=34.65 \%$. It indicates that the model related to the variable is categorized as weak. The result also shows that PEJ and CSE can only explain the PEoU as much as $34.65 \%$. Additionally, PU shows that the value of R2 $=9.7 \%$. It means that PEoU can only explain PU as much as $9.7 \%$. Regarding the predictive relevance (Q2), the model's criterion has predictive relevance if the value of Q2 is above 0 (Hair et al., 2017). Viewed in Figure 2, the value of Q2 of the satisfaction variable is 0.419 , while the value of Q2 of the PU variable is 0.058. Lastly, the value of Q2 of the PEoU variable is 0.264 . It shows that the value of Q2 of each variable (satisfaction, PU, and PEoU) is above 0 , which means the model in this research has predictive relevance. Figure 2 shows the results of the structural test covering the coefficient determination (R2), predictive relevance $(\mathrm{Q} 2)$, and the significance of path coefficient $(\beta)$.

The data analysis results show that PU $(\beta=0.5140)$ positively and significantly affects the satisfaction of using Google Classroom. The result of this research is in line with some previous research (Cho, 2016; Hossain et al., 2019; Hu \& Zhang, 2016; Pal, Funilkul, \& Vanijja, 2018; Park, 2020; Kumar, Israel \& Malik, 2018; Park, 2020; Chiu, Cho \& Chi, 2020). It indicates that students who believe that Google Classroom has benefits in the learning activities will have a higher level of satisfaction. If one path coefficient is more than the others, it can be concluded that the variable has a significant effect (Hair et al., 2017). Based on this information, the data analysis results show that PU $(\beta=0.5140)$ has the most substantial effect the satisfaction than the other variables. Viewed from the educational practices, before using Google Classroom as LMS, lecturers need to understand the advantages and benefits gained by the students. 
It requires lecturers to provide students information about the advantages or benefits gained when using Google Classroom. For example, using Google Classroom can accomplish and submit their work anywhere and anytime without seeing the lecturers in person. They can ask questions and conduct discussions easily, both with peers and the lecturers. It is just like giving comments on Facebook, and they can easily download materials shared by their lecturers in Google Classroom. The more information about the functions and advantages of Google Classroom got by students, the higher the perception of function, which later leads to a high level of satisfaction. When the level of satisfaction is high, in the end, it affects the level of student's involvement in the teaching and learning process.

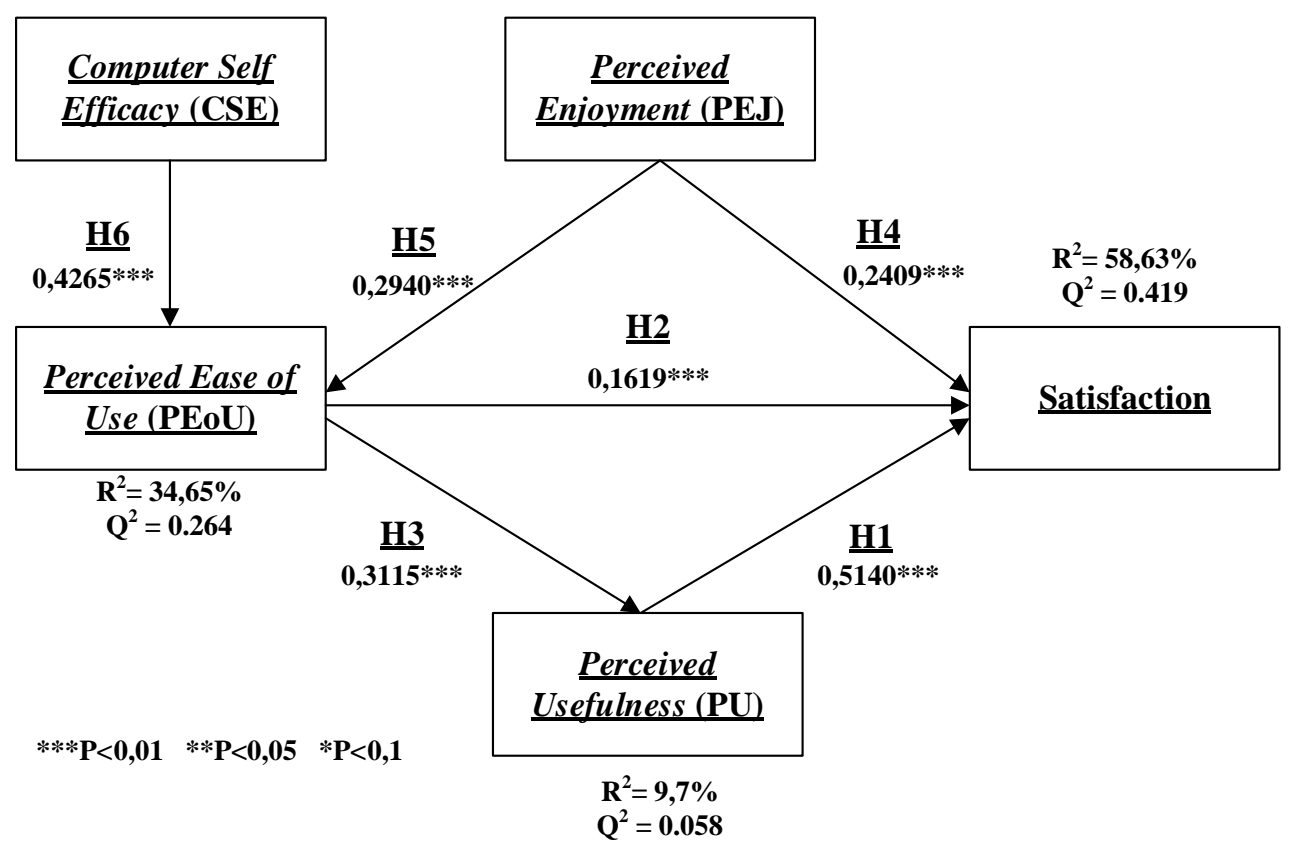

Figure 2. Results of Hypothesis Testing, Coefficient of Determination \& Predictive Relevance

Meanwhile, PEoU $(\beta=0.1619)$ positively and significantly affects the satisfaction of using Google Classroom. It means that students who feel that learning through Google Classroom does not need any effort and believe that Google Classroom is userfriendly will have a higher level of satisfaction. This result is in line with some previous research (Cho, 2016; Natarajan et al., 2017; Cheng \& Yuen, 2018; Humbani \& Wiese, 2019). It means that lecturers need to shape students' perception that using Google Classroom is painless and does not need much time to learn how to use it. One way that can be conducted is by telling them that Google Classroom features are similar to that of social media apps. Besides, lecturers also need to understand that using LMS in the teaching and learning process can be divided into three levels (Malikowski, Thompson, \& Theis, 2007; Sezer \& Yilmaz, 2019). The first level is that LMS is only used to deliver materials. Second, LMS is used to conduct an assessment and to build interaction between lecturers and students or among students; for example, conducting the discussion, quizzes, and other types of assignments. Third, LMS is used not only to give assignments or conduct discussions, but also to assess the class and the lecturers as well; for example, questionnaires or scales to measure the satisfaction of the class joined or the lecturer's performance. Regarding this division, lecturers need to use Google Classroom gradually based on the grouped level so that the perception that (i) (2)

This work is licensed under a Creative Commons Attribution-ShareAlike 4.0 International License. 
using Google Classroom is easy will arise. At the first level, Google Classroom is only used to deliver materials, and in the next levels, it is used to conduct discussion, give assignments, and so on.

PEoU $(\beta=0.3115)$ positively and significantly affects PU. This result shows that students who feel using Google Classroom is comfortable will believe that it is useful. This result is confirming the previous research (Cho, 2016; Hu \& Zhang, 2016; Kabbiri et al., 2018; Hassan \& Wood, 2020; Dumpit \& Fernandez, 2017; Natarajan et al., 2017; Torres \& Gerhart, 2017; Youn \& Lee, 2019). If it were difficult for students to use LMS, students would have hostile attitudes to LMS's usefulness and give it up to use the LMS. This result means that the efforts are made to improve PEoU, increase satisfaction, and increase PU. PEoU of information technology is connected to usability design (Thong et al., 2006). From this perspective, the LMS developer should pay more attention to designing LMS easy to use. Besides, the role of the lecturer in shaping students' perceptions about LMS is also essential. Lecturers need to provide understanding to students that it is not challenging to use LMS for teaching and learning activities, such as collecting assignments, downloading material, and seeing announcements.

Ultimately, regarding the determinant of satisfaction in using Google Classroom, PEJ has a positive and significant effect. This result is in line with some previous research (Azian et al., 2017; Natarajan et al., 2017; Joo et al., 2017; Coşkunçay, Alkış, \& Ylldırım, 2018 Park, 2020). It means that students who find comfort and enjoyment using Google Classroom will have a higher level of satisfaction. Besides communicating the function and benefit of Google Classroom, lecturers also need to design attractive and fun teaching and learning activities using Google Classroom. If PEJ is explored through exciting learning activities, it will affect the student's perception that using Google Classroom is easy and elevates their satisfaction. Attractive learning design with Google Classroom, for example, by organizing quiz through Google Classroom. Quiz in Google Classroom can be designed like a game where students can answer faster than the others, and they can get higher points. This is in line with the result of research Venkatesh \& Speier (2000), who found that gamebased training methods aimed at enhancing intrinsic motivation resulted in higher enjoyment and PEoU than the traditional training method.

Meanwhile, CSE $(\beta=0.4265)$ and PEJ $(\beta=0.2940)$ positively and significantly affect PEoU. The result shows that students who feel competent to use a computer will find no significant difficulties in using Google classroom. Moreover, it can be stated that students who feel it fun using Google Classroom will also find no difficulties in using Google Classroom. Related to the PEJ, this result is in line with some previous research (Thong et al., 2006; Huang et al., 2020). It means that students who derive enjoyment from using the LMS will not view its usage as effortful. This result suggests that students are young LMS users, their sense of enjoyment in using LMS, which drives LMS usage for learning, and the more students PEJ, the more likely they form their PEoU. The practical impact of this finding, lecturers need to make assignments through LMS in exciting and fun ways to increase students' PEJ of LMS. These efforts can increase the PEoU and can increase satisfaction with LMS. This result is related to CSE in line with previous research (Huang et al., 2020; Yalcin \& Kutlu, 2019). This finding echoes the concept of digital natives. The digital natives suggest that growing up with Internet technology. Young students are usually very familiar with technologies with Internet connection (ex: google classroom) (Huang et al., 2020). This result practically implies that higher education applying LMS needs to make sure students can use a computer because it affects their perception about the ease of using Google Classroom. 
When students have been ater, they will have a perception that using Google Classroom is easy, and later, it can elevate the level of satisfaction of using Google Classroom as the LMS.

\section{CONCLUSION}

The results of this research show that PEJ, PEoU and PU positively and significantly affect the Accounting students' satisfaction in using Google Classroom. PEoU positively and significantly affects PU. Moreover, CSE and PEJ positively and significantly affect PEoU. Based on the results of this research, the crucial implications in the practical context are as follow. Lecturers need to actively deliver information about the advantages and functions of Google Classroom. Then, they need to shape students' perception that using Google Classroom is easy. Additionally, they also need to concern about students' ability to use a computer.

Although this research has succeeded in testing the factors affecting the level of satisfaction in using Google Classroom, it is still limited to only viewed from students' points of view. Future research can view it from lecturers. It is crucially concerning because seeing the different roles in using LMS will affect the level of satisfaction. Moreover, this research's satisfaction model is categorized moderate, so it is better to conduct future research with other relevant variables. It is expected that future research will be able to give better explanations related to factors affecting satisfaction in using LMS. Ultimately, future research also needs to concern about moderation variables such as gender, age, location, and the like.

\section{REFERENCES}

Azian, N., Rahman, A., Hussein, N., Rusdi, S. D., \& Esa, M. M. (2017). Examining the Factors that Influence Blended Learning Satisfaction Among Tertiary Students in a Public University in Malaysia. World Applied Sciences Journal, 35(4), 580-584. https:// doi.org/10.5829/idosi.wasj.2017.580.584

Bandura, A. (1986). Social foundations of thought and action: A social cognitive theory. Englewood Cliffs, NJ.

Basioudis, I. G., Lange, P. de, Suwardy, T., \& Wells, P. (2012). Accounting students' perceptions of a Learning Management System: An international comparison. Accounting Research Journal, 25(2), 72-86. https://doi.org/http:/ /dx.doi.org/10.1108/MRR-09-2015-0216

Cheng, M., \& Yuen, A. H. K. (2018). Student continuance of learning management system use: A longitudinal exploration. Computers and Education, 120(June), 241-253. https:// doi.org/10.1016/j.compedu.2018.02.004

Chiu, W., Cho, H., \& Chi, C. G. (2020). Consumers' continuance intention to use fitness and health apps: an integration of the expectation-confirmation model and investment model. Information Technology and People. https:/ / doi.org/10.1108/ITP-09-2019-0463

Cho, J. (2016). The impact of post-adoption beliefs on the continued use of health apps. International Journal of Medical Informatics, 87, 75-83. https:// doi.org/10.1016/j.ijmedinf.2015.12.016

Cigdem, H., \& Topcu, A. (2015). Predictors of instructors' behavioral intention to use learning management system: A Turkish vocational college example. Computer in Human Behavior, 52, 22-28. https:// doi.org/10.1016/j.chb.2015.05.049

Compeau, D. R., \& Higgins, C. A. (1995). Computer Self-Efficacy: Development of a Measure and Initial Test. MIS Quarterly, 19(2), 189-211. 
Coşkunçay, D. F., Alkış, N., \& Yıldırım, S. Ö.-. (2018). International Forum of Educational Technology \& Society A Structural Equation Model for ICT Usage in Higher Education Published by : International Forum of Educational Technology \& Society Linked references are available on JSTOR for this article: A Stru. Educational Technology \& Society, 21(2), 13-27.

Dash, S. (2019). Google Classroom as a Learning Management System to Teach Biochemistry in a Medical School. Biochemistry and Molecular Biology Education, 1-4. https:// doi.org/10.1002/bmb.21246

Davis, F. D. (1989). Perceived Usefulness, Perceived East of Use, and User Acceptance of Information Technology. MIS Quarterly, 13(3), 319-340. https://doi.org/10.1016/S0305-0483(98)00028-0

Davis, F. D., Bagozzi, R. P., \& Warshaw, P. R. (1989). User acceptance of computer technology: a comparison of two theoretical models. Management Science, 35(8), 982-1003. https://doi.org/10.1287/mnsc.35.8.982

Davis, F. D., Bagozzi, R. P., \& Warshaw, P. R. (1992). Extrinsic and intrinsic motivation to use computers in the workplace. Journal of Applied Social Psychology, 22(14), 1111-1132. https://doi.org/10.1111/j.1559-1816.1992.tb00945.x

Dumpit, D. Z., \& Fernandez, C. J. (2017). Analysis of the use of social media in Higher Education Institutions (HEIs) using the Technology Acceptance Model. International Journal of Educational Technology in Higher Education, 14(1). https://doi.org/10.1186/s41239-017-0045-2

Hassan, H. E., \& Wood, V. R. (2020). Does country culture influence consumers' perceptions toward mobile banking? A comparison between Egypt and the United States. Telematics and Informatics, 46, 1-13. https://doi.org/10.1016/j.tele.2019.101312

Hair, J. F., Hult, G. T. M., Ringle, C. M., \& Sarstedt, M. (2017). A Primer on Partial Least Squares Structural Equation Modeling ( PLS-SEM ) (Second Edition). Los Angeles: Sage Publications.

Hayashi, A., Chen, C., Ryan, T., \& Wu, J. (2004). The Role of Social Presence and Moderating Role of Computer Self Efficacy in Predicting the Continuance Usage of E-Learning Systems. Journal of Information Systems Education, 15(2), 5.

Hidayat, M. W. (2018). E-Learning Makin Menarik Perhatian di 2018. Retrieved from https://www.liputan6.com/tekno/read/3226423/e-learning-makin-menarikperhatian-di-2018

Hossain, S. F. A., Nurunnabi, M., Hussain, K., \& Saha, S. K. (2019). Effects of varietyseeking intention by mobile phone usage on university students' academic performance. Information and Communications Technology in Education, 6(1), 1-18. https:// doi.org/10.1080/2331186X.2019.1574692

$\mathrm{Hu}$, J., \& Zhang, Y. (2016). Understanding Chinese Undergraduates ' Continuance Intention to Use Mobile Book-Reading Apps: An Integrated Model and Empirical Study. International Journal of Libraries and Information Studies, 66(2), 1-15. https://doi.org/10.1515/libri-2015-0090

Huang, F., Teo, T., \& Scherer, R. (2020). Investigating the antecedents of university students' perceived ease of using the Internet for learning. Interactive Learning Environments, 28(1), 1-17. https:/ / doi.org/10.1080/10494820.2019.1710540

Humbani, M., \& Wiese, M. (2019). An integrated framework for the adoption and continuance intention to use mobile payment apps. International Journal of Bank Marketing, 37(2), 646-664. https:// doi.org/10.1108/IJBM-03-2018-0072

Jakkaew, P. (2017). The Use of UTAUT2 Model for Understanding Student Perceptions Using Google Classroom: A Case Study of Introduction to Information 
Technology Course. In International Conference on Digital Arts, Media and Technology (ICDAMT). Chiang Mai, Thailand: IEEE. Retrieved from https:/ / ieeexplore.ieee.org/document/7904962

Joo, Y. J., Park, S., \& Shin, E. K. (2017). Students' expectation, satisfaction, and continuance intention to use digital textbooks. Computers in Human Behavior, 69, 83-90. https:/ / doi.org/10.1016/j.chb.2016.12.025

Jordan, M. M., \& Duckett, N. D. (2018). Universities Confront 'Tech Disruption': Perceptions of Student Engagement Online Using Two Learning Management Systems. The Journal of Public and Professional Sociology, 10(1), 1-25.

Kabbiri, R., Dora, M., Kumar, V., Elepu, G., \& Gellynck, X. (2018). Mobile phone adoption in agri-food sector: Are farmers in Sub-Saharan Africa connected? Technological Forecasting and Social Change, 131(December 2016), 253-261. https://doi.org/10.1016/j.techfore.2017.12.010

Kholid, M. N., Urumsah, D., \& Hamdani, R. (2018). Expectation Confirmation Model in the Transportation Order Applications: Gender Differences. In 31st IBIMA Conference. Milan Italy. Retrieved from https://ibima.org/acceptedpaper/expectation-confirmation-model-in-the-transportation-order-applicationsgender-differences/

Kumar, J. A., \& Bervell, B. (2019). Google Classroom for mobile learning in higher education: Modelling the initial perceptions of students. Education and Information Technologies, 24(2), 1793-1817.

Kumar, R. R., Israel, D., \& Malik, G. (2018). Explaining customer's continuance intention to use mobile banking apps with an integrative perspective of ECT and Self-determination theory. Pacific Asia Journal of the Association for Information Systems, 10(2), 79-112. https:/ / doi.org/10.17705/1pais.10204

Lonn, S., \& Teasley, S. D. (2009). Saving time or innovating practice: Investigating perceptions and uses of Learning Management Systems. Computers and Education, 53(3), 686-694. https://doi.org/10.1016/j.compedu.2009.04.008

Malikowski, S. R., Thompson, M. E., \& Theis, J. G. (2007). A Model for Research into Course Management Systems: Bridging Technology and Learning Theory. Journal Educational Computing Research, 36(2), 149-173.

Marinkovic, V., \& Kalinic, Z. (2017). Antecedents of customer satisfaction in mobile commerce of customization. Online Information Review, 41(2), 138-154. https://doi.org/10.1108/OIR-11-2015-0364

Natarajan, T., Balasubramanian, S. A., \& Kasilingam, D. L. (2017). Understanding the intention to use mobile shopping applications and its in fl uence on price sensitivity. Journal of Retailing and Consumer Services, 37, 8-22. https://doi.org/10.1016/j.jretconser.2017.02.010

Pal, D., Funilkul, S., \& Vanijja, V. (2018). The future of smartwatches: assessing the endusers' continuous usage using an extended expectation-confirmation model. Universal Access in the Information Society, 19(2), 261-281. https://doi.org/10.1007/s10209-018-0639-z

Park, E. (2020). User acceptance of smart wearable devices: An expectationconfirmation model approach. Telematics and Informatics Journal, 47, 1-11. https://doi.org/10.1016/j.tele.2019.101318

Roca, J. C., Chiu, C. M., \& Martínez, F. J. (2006). Understanding e-learning continuance intention: An extension of the Technology Acceptance Model. International Journal of Human Computer Studies, 64(8), 683-696. https://doi.org/10.1016/j.ijhcs.2006.01.003 
Sezer, B., \& Yilmaz, R. (2019). Learning management system acceptance scale (LMSAS): A validity and reliability study. Australasian Journal of Educational Technology, 35(3), 15-30.

Teddie, C., \& Yu, F. (2007). Mixed Methods Sampling: A Typology With Examples. Journal of Mixed Methods Research, 1(1), 77-100. https://doi.org/10.1177/2345678906292430

Teo, T., Ursavaş, O. F., \& Bahçekapili, E. (2012). An assessment of pre-service teachers' technology acceptance in Turkey: A structural equation modeling approach. Asia-Pacific Education Researcher, 21 (July 2016), 191-202. 84858763296\&partnerID=40\&md5=ef3aac58ae408c5dcc82c482d62e6f92

Thong, J. Y. L., Hong, S. J., \& Tam, K. Y. (2006). The effects of post-adoption beliefs on the expectation-confirmation model for information technology continuance. International Journal of Human Computer Studies, 64(9), 799-810. https://doi.org/10.1016/j.ijhcs.2006.05.001

Torres, R., \& Gerhart, N. (2017). Mobile Proximity Usage Behaviors Based on User Characteristics. Journal of Computer Information Systems, 59(2), 1-10. https:// doi.org/10.1080/08874417.2017.1320954

Vaezi, R., Mills, A., Chin, W., \& Zafar, H. (2016). User Satisfaction Research in Information Systems: Historical Roots and Approaches. Communications of the Association for Information Systems, 38(27), 501-532.

Yalcin, M. E., \& Kutlu, B. (2019). Examination of students' acceptance of and intention to use learning management systems using extended TAM. British Journal of Educational Technology, 0(0), 1-19. https:/ / doi.org/10.1111/bjet.12798

Youn, S. yi, \& Lee, K. H. (2019). Proposing value-based technology acceptance model: testing on paid mobile media service. Fashion and Textiles, 6(1). https://doi.org/10.1186/s40691-018-0163-z

Venkatesh, V., \& Speier, C. (2000). Creating an effective training environment for enhancing telework. Journal Human Computer Studies, 52, 991-1005. https://doi.org/10.1006/ijhc.1999.0367 